\title{
Comparative Anatomy of Blue-and-Yellow Macaw (Ara ararauna) and Toco Toucan (Ramphastos toco) Beaks Using Macroscopic Analysis and Computerized Tomography
}

\author{
Anatomía Comparada de los Picos de Guacamayo Azul y Amarillo (Ara ararauna) y de \\ Tucán Toco (Ramphastos toco) Mediante Análisis Macroscópico y Tomografía Computarizada
}

Catia Helena de Almeida Lima Massari' ${ }^{1}$ Adriano Ferreira Silva ${ }^{1}$; Henrique Inhauser Riceti Magalhães ${ }^{1}$; Dara Rúbia Souza Silva ${ }^{1}$; Taís Harumi de Castro Sasahara ${ }^{1}$ \& Maria Angélica Miglino ${ }^{1}$

\begin{abstract}
MASSARI, C. H.A. L.; SILVA, A. F.; MAGALHÃES, H. I. R.; SILVA, D. R. S.; SASAHARA, T. H. C. \& MIGLINO, M.A. Comparative anatomy of blue-and-yellow macaw (Ara ararauna) and toco toucan (Ramphastos toco) beaks using macroscopic analysis and computerized tomography. Int. J. Morphol., 38(6):1591-1596, 2020.

SUMMARY: Clinically, avian medicine still finds it very difficult to treat wild patients due to the lack of reliable information about their anatomy and physiological parameters that make comparative analyzes possible. Considering that computed tomography (CT) is one of the most viable alternatives in radiography of the head, we describe the comparative anatomy of the beak in the Ara ararauna and the Ramphastos toco through this imaging modality and macroscopy analysis, providing additional information about their conformation and topography for clinical exams. Adult specimens of each were dissected after the CT and beaks were removed for macroscopic analyses. The macroscopic and tomographic findings for both species confirm the similarities in beak morphology and the dietary peculiarities of each. The CT scan proved to be a useful tool to visualize internal structures of the skull through a detailed virtopsy of regions that are difficult to access by the usual necropsy with a scalpel.
\end{abstract}

KEY WORDS: Bird anatomy; Morphology; Skull; Tomography exam.

\section{INTRODUCTION}

According to the $5^{\text {th }}$ National Report for the Convention on Biological Diversity, Brazil is the country with the greatest biodiversity in the world (Ministério do Meio Ambiente, 2016). When considering avian species alone, it assumes a tertiary position only behind Colombia and Peru (BirdLife International, 2013). The economic exploration, intense destruction of habitats and illegal persecution of birds that represent this fauna place these animals under constant threat (Cubas et al., 2014).

The Blue-and-yellow Macaw (Ara ararauna) are parrots that are widely distributed in Brazilian territory as well as the southern region of Central America (Scherer-Neto et al., 2011). It is one of the main targets for trafficking of wild species, especially since it adapts easily in captivity, and for the beauty of its exuberantly colorful plumage (Bianchi, 1998). Generally, they feed on fruits, seeds, flowers and leaves, which can vary depending on the region and available environmental resources (Tubelis, 2009). The ventrally curved beak of these birds is especially adept for collecting and handling their food (Cubas et al.).

The Toco Toucan (Ramphastos toco) is a ranphastid widespread distributed throughout neotropical regions, occupying an area that extends from southern Mexico to northern Argentina. It is morphologically easy to identify, due to its large and long beak (Cubas et al.). Currently, it is accepted that this characteristic is related to body thermoregulation (Tattersall et al., 2009) and feeding aspects of fruit peeling (Jones, 1985), nest predation (Sick, 1997), and greater reach within holes in trees (Short \& Horne, 2001).

Clinically, avian medicine still finds it very difficult to cope with wild patients even when in captivity, inasmuch, as little is known of crucial pathological signs in these animals (Veladiano et al., 2016). Diagnostic approaches have become

${ }^{1}$ Department of Surgery, School of Veterinary Medicine and Animal Sciences, University of São Paulo, Brazil. 
MASSARI, C. H. A. L.; SILVA, A. F.; MAGALHÃES, H. I. R.; SILVA, D. R. S.; SASAHARA, T. H. C. \& MIGLINO, M. A. Comparative anatomy of blue-and-yellow macaw (Ara ararauna) and toco toucan (Ramphastos toco) beaks using macroscopic analysis and computerized tomography. Int. J. Morphol., 38(6):1591-1596, 2020.

more important and, despite the great advance in the area over the past 20 years (Krautwald-Junghanns, 2010), there is still little information on physiological parameters to make comparative analyzes possible, especially for imaging tests in the region of their heads (Veladiano et al.).

As computerized tomography (CT) is one of the most viable alternatives in radiology, mainly because it avoids a structural overlap through higher spatial resolution (Krautwald-Junghanns). We aim to describe the comparative anatomy of the beaks of the Blue-and-yellow Macaw and Toco Toucan using CT and macroscopy analysis, to provide additional information on their conformation and topography for use in clinical routine. It is also expected to observe relationships between structural aspects and their eating habits.

\section{MATERIAL AND METHOD}

Three adult specimens of Blue-and-yellow Macaw (Ara ararauna) and Toco Toucan (Ramphastos toco) were donated to the scientific repository of the Animal Anatomy Laboratory of the Department of Surgery of the School of Veterinary Medicine and Animal Science of the University of São Paulo (USP-Brazil) by the Marinovic maintainer; authorized by the Brazilian Institute of Environment and Renewable Natural Resources (IBAMA) by protocol n 3127.9144/2014-MG.

Tomographic examination of the cadavers was performed in Phillips ${ }^{\circledR}$ Brilliance CT scanner with 64 rows of sectors from the Imaging Service of the University of São Paulo, and DICOM format (digital imaging and communications in medicine) was used to save the images. All content was analyzed by $\operatorname{Radiant}^{\circledR}$ Medical Image processing software and Osirix ${ }^{\circledR}$. Next, the animals were fixed by means of intramuscular, subcutaneous, and intracavitary injections of $10 \%$ formaldehyde aqueous solution prior being immersed in opaque tanks containing the same solution, where they remained for 15 days. Dissections began only after that period, and were performed according to procedures established at the Laboratory.

The nomenclature used to designate the identified structures was in accordance with the International Committee on Avian Anatomical Nomenclature (ICAAN) (Baumel et al., 1993) and, when applicable, with the International Committee on Veterinary Gross Anatomical Nomenclature (International Committee on Veterinary Gross Anatomical Nomenclature, 2017). The study was approved by the Ethics Committee on the use of Animals of University of São Paulo (protocol number 5351110320), and by the SISBIO-Brazil (protocol number 72069-1).

\section{RESULTS}

Multiplanar reconstructions were generated in dorsal, sagittal and transverse sections, in addition to the three-dimensional volumetric rendering of the bodies of both wild birds. The beak consisted of a very resistant and, at the same time, lightweight structure, formed by a network of very thin bone trabeculae that make it possible to have ample internal space.

For both species, the maxillary and mandibular parts of the beak, respectively, are supported on the pre-maxillary and mandibular pneumatic bones. These are recovered by a hard keratinized layer. Together, these structures are called rhamphotheca, the rhinotheca for the upper region and the gnathotheca for the lower region (Figs. 1, 2 and 3).

For both species, the external region of the beak comprises the angle of the dorsal midline of the rhinotheca, called culmen; the angle of the ventral midline of the gnathotheca, called gonys; and the cutting region of the right and left lateral margins of both parts of the rhanphotheca, called tomia (it is serrated in the Toco Toucan, but an unguis in the Blue-and-yellow Macaw) (Figs. 1 and 2).

Macroscopically, as well as detected through the threedimensional reconstruction with differentiation of tissue density by colors, a general thickening of these three regions was visualized, as they were positioned rostrally towards the apex of the beak, being a more compact tissue (Figs. 1, 2 and 3 ). The structures containing air tend to appear darker while the solid structures tend to color in red (Fig. 3).

In the Toco Toucan, the mandibular part is formed by two rami that merge in the midline, in a dorsal view, constituting a lower median raphe that supports the tongue when it is at rest; and the maxillary part is formed by the fusion of the ramus of the pre-maxillary bones, which in a ventral view, form an upper median raphe. It is noteworthy that both are morphologically similar to a gutter (Fig. 1).

In the Blue-and-yellow Macaw the rostral third of the ventral part of the rhamphotheca consisted of palatal wrinkles, transversely arranged and individualized from the rest of the beak by a step-shaped depression. The apex of its beak is strongly curved in a ventral direction, similar to a hook, and the mandibular part is short with the apex analogous to a spatula (Fig. 2), unlike the toucan which looks like a clamp (Fig. 1).

Through the median sagittal section using computerized tomography, for both species, the internal region of the beak is, generally, constituted by an extensive 


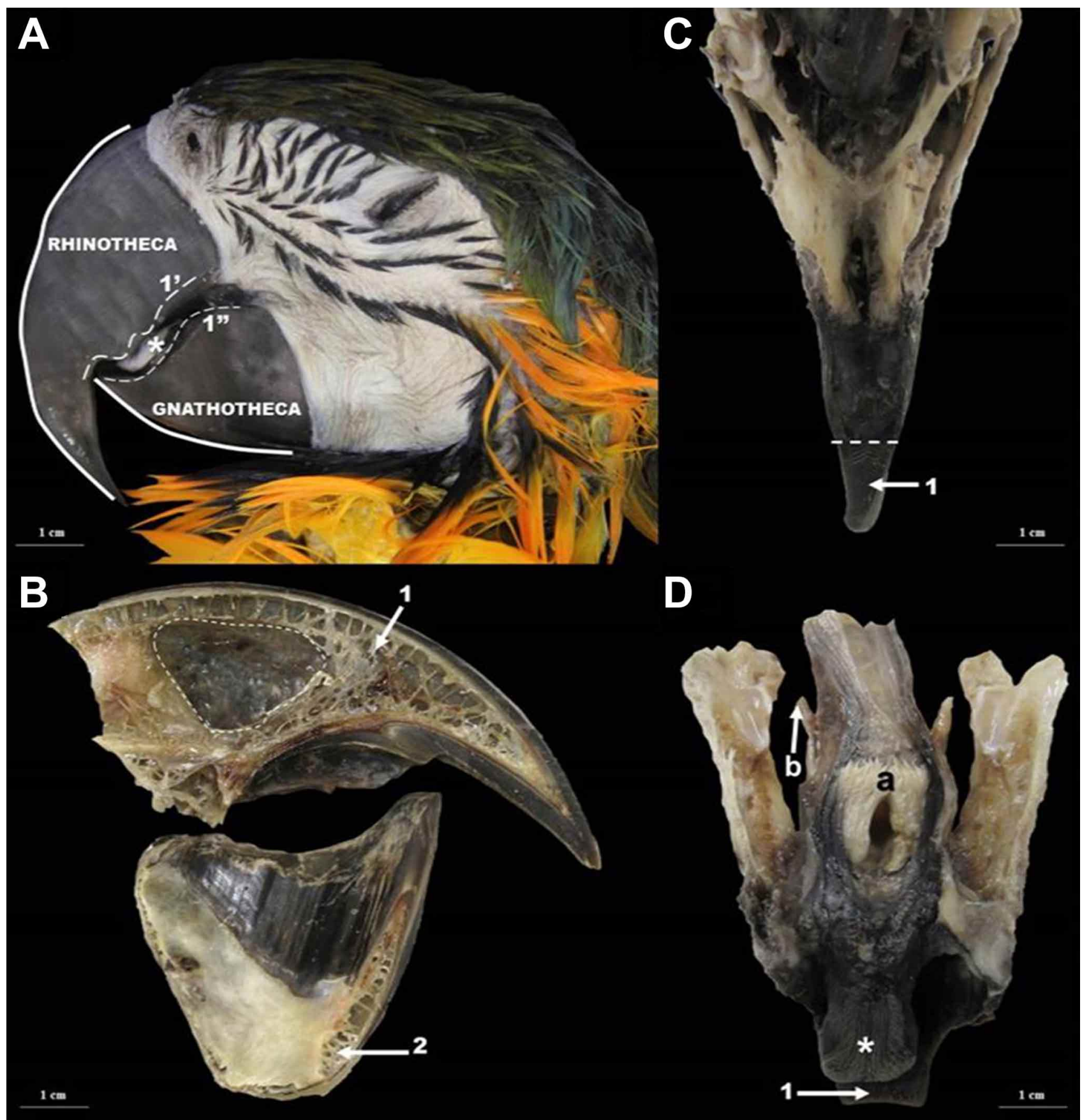

Fig. 1. Specimen of Blue-and-yellow Macaw (Ara ararauna). (A) Left side view showing the region of culmen and gonys (white lines), and the superior (1') and inferior tomia (1"). (B) Medial view of the left hemibeak after a mid-sagittal cut indicating the maxillary chamber (dashed line) and the trabecular bone network in the maxillary (1) and mandibular (2) parts of the beak. (C) Ventral view of the maxillary part of the beak showing the step-shaped depression (dashed line) and the area of the palatal folds (1). (D) Dorsal view with the mandibular part of the beak removed together with the larynx (a) and hyoid bone (b), referencing the rostral limit of the mandibular part (1). $(*)$ demonstrates the tongue.

interconnected trabecular bone network (Figs. 1, 2 and 4). Sometimes, this is not present and just delimits a large internal space, the maxillary chamber (Figs. 1, 2 and 5). The trabecular tissue was thinner and had a greater number of branches in the Toco Toucan when compared to the Blue-and-yellow Macaw (Figs. 1 and 2). 


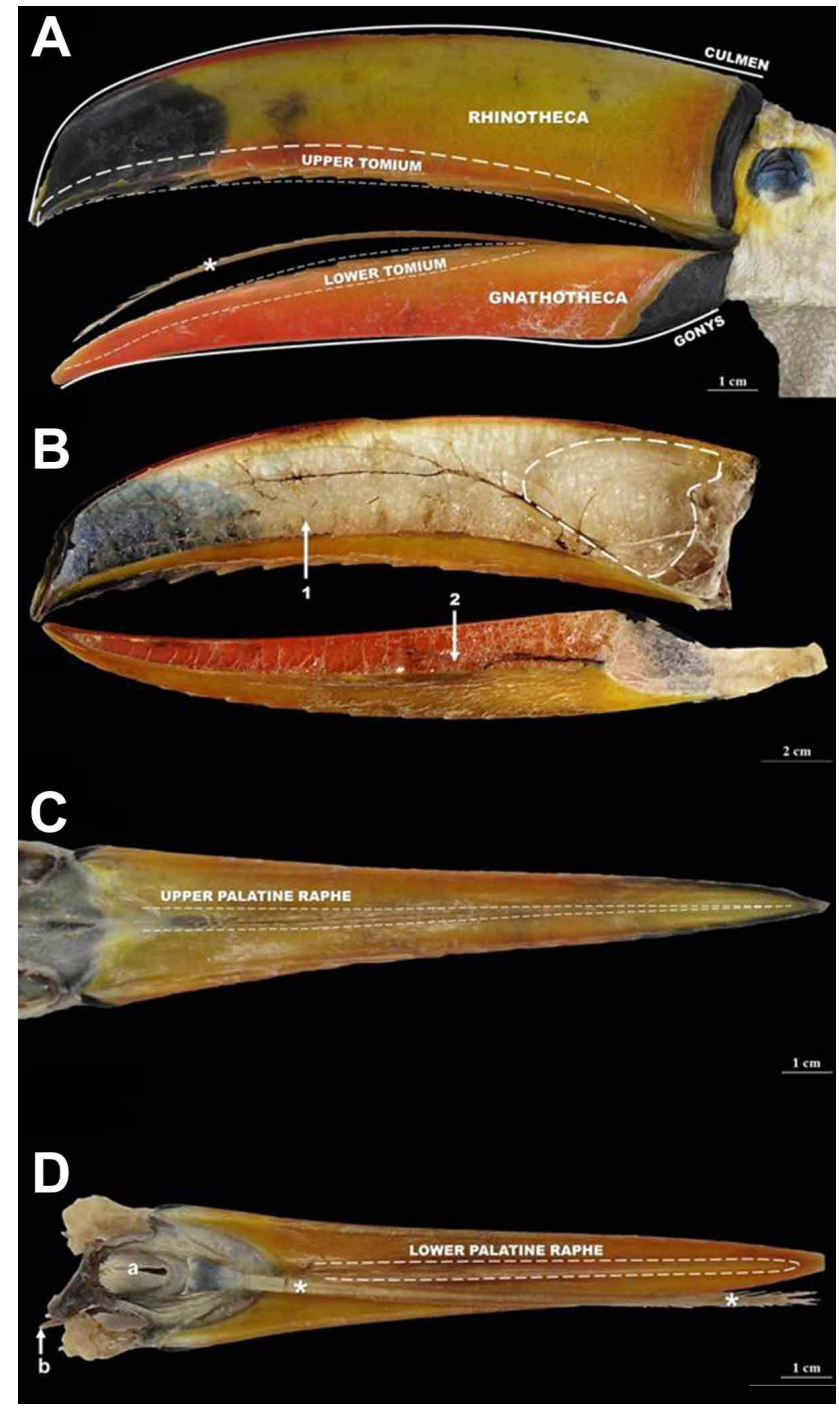

Fig. 2. Specimen of Toco Toucan (Ramphastos toco). (A) Left side view showing the region of culmen, gonys (white lines), and upper and lower tomia (dashed lines). (B) Medial view of the right hemibeak after a median sagittal cut indicating the maxillary chamber (dashed line) and the trabecular bone network in the maxillary (1) and mandibular (2) parts of the beak. (C) Ventral view of the maxillary part of the beak showing the upper median raphe (dashed line). (D) Dorsal view with the mandibular part of the beak removed along with the larynx (a) and hyoid bone (b), referencing the lower median raphe (dashed line). $(*)$ demonstrates the tongue.

\section{DISCUSSION}

The understanding of function is necessary to comprehend the peculiar shape of these birds' beaks. The study on the "Form-Function" complex defines that "form is the plastic image of function", that is, for anatomy, form appears as "a fixed moment of function" (Ruffini, 1925).
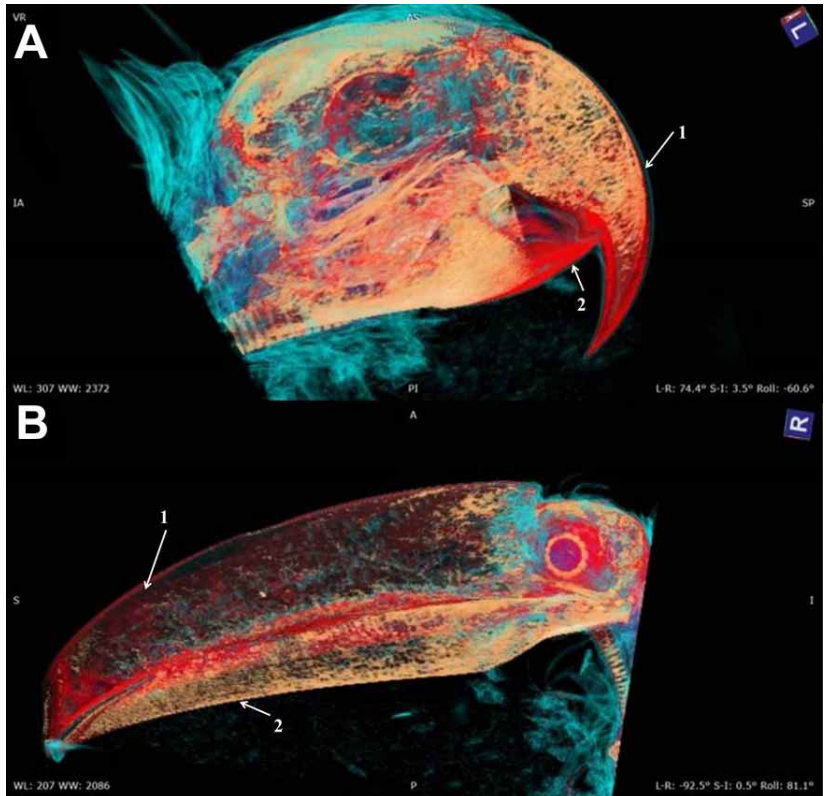

Fig. 3. Visualization of the rhinotheca (1) and gnathotheca (2) in Blue-and-yellow Macaw (Ara ararauna) (A) and Toco Toucan (Ramphastos toco) (B). It is also observed the differentiation of density of the component tissues in species, referring to the more intense red, the greater the density of this tissue.

The Blue-and-yellow Macaw with its beak in the form of a rigid hook needs to open the seeds and fruits for feeding, in addition to also using it as a tool to climb trees (Cubas et al.).

The Toco Toucan, on the other way, uses its beak to capture food by destroying the nests of other birds and inside cavities in trees (Sick). It also forages for fruits that are not easily accessible in treetops (Short \& Horne, 2001). Since it has a significant surface area for heat exchange, the beak is also used as a thermoregulator, similar to a radiator in an automobile (Tattersall et al.).

A thin and extensive trabecular bone network is present inside both the maxillary and mandibular parts of the beaks of both species. This corroborates what has already been reported by Short \& Horne (2002), Seki et al. (2006), Fecchio et al. (2010), Seki et al. (2010) and Dislich (2014) for the latter. Similar information was not available for the Blue-and-yellow Macaw, as the description published by Aizawa et al. (2013) did not address this anatomical region. This is also the first time that the beak of these two species is described through this imaging technique.

Such images are of great value for Veterinary Medicine (Krautwald-Junghanns). Computerized tomography 

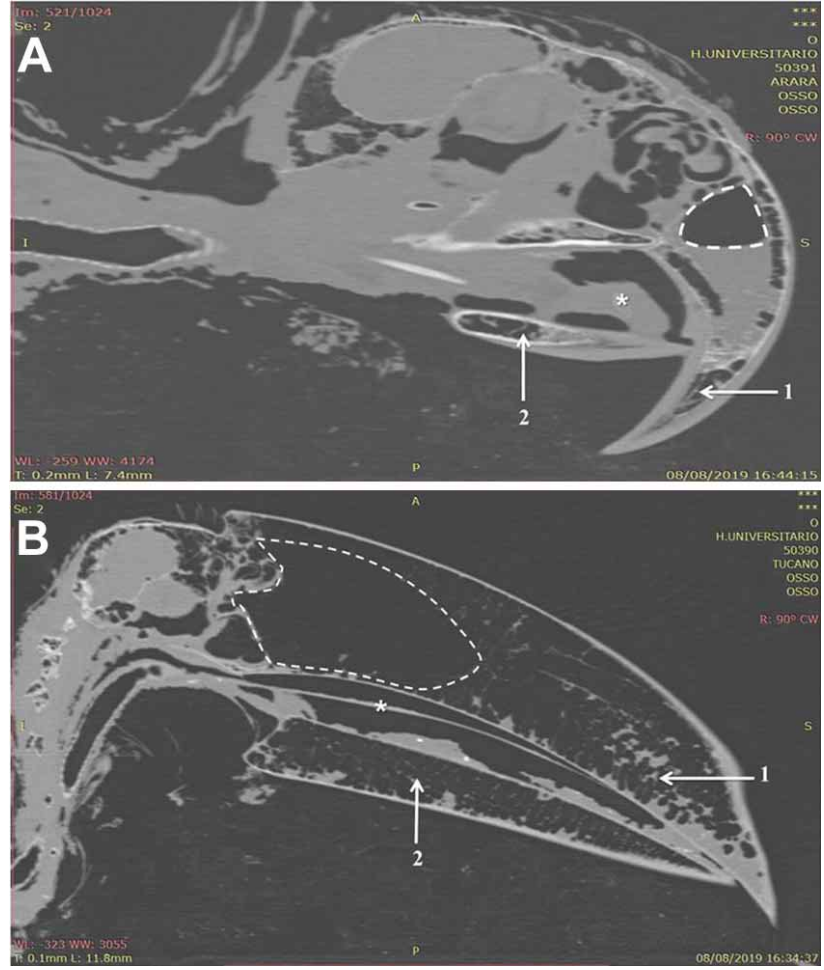

Fig. 4. In the sagittal section, the maxillary chamber (dashed line), and the trabecular bone network in the maxillary (1) and mandibular (2) parts of the Blue-and-yellow Macaw (Ara ararauna) (A) and Toco Toucan (Ramphastos toco) (B) beaks are demonstrated. (*) demonstrates the tongue.

offers high spatial resolution and allows for the evaluation of more complex anatomical structures, being clinically valuable in the identification of tumors and/or fluids within the paranasal sinuses and nasal chambers during avian medical routine (Hillyer, 1997). Sinusitis, for example, is one of the most common respiratory problems in psittacine birds (Altman, 1997), also occurring quite frequently in ranfastids, which are susceptible to this disease. This is due to the peculiar form their beaks which favors the growth of aerobic bacteria and the accumulation of necrotic and caseous materials between bone trabeculae (Dislich). In some specific cases, the clinical condition of patients can be unresponsive to conventional therapies and a chronic condition can be reached, either due to the resistance of pathogens, or the presence of some tumor or granuloma (Hillyer). However, medical therapy can be effective once both situations are solved (Pye et al., 2000), and so it is essential to have a broad understanding of local physiological anatomy (Orosz, 1997). We contribute via anatomical and tomographic images for the Blue-and-yellow Macaw and Toco Toucan.

The macroscopic and tomographic findings for both the Blue-and-yellow Macaw and Toco Toucan corroborate

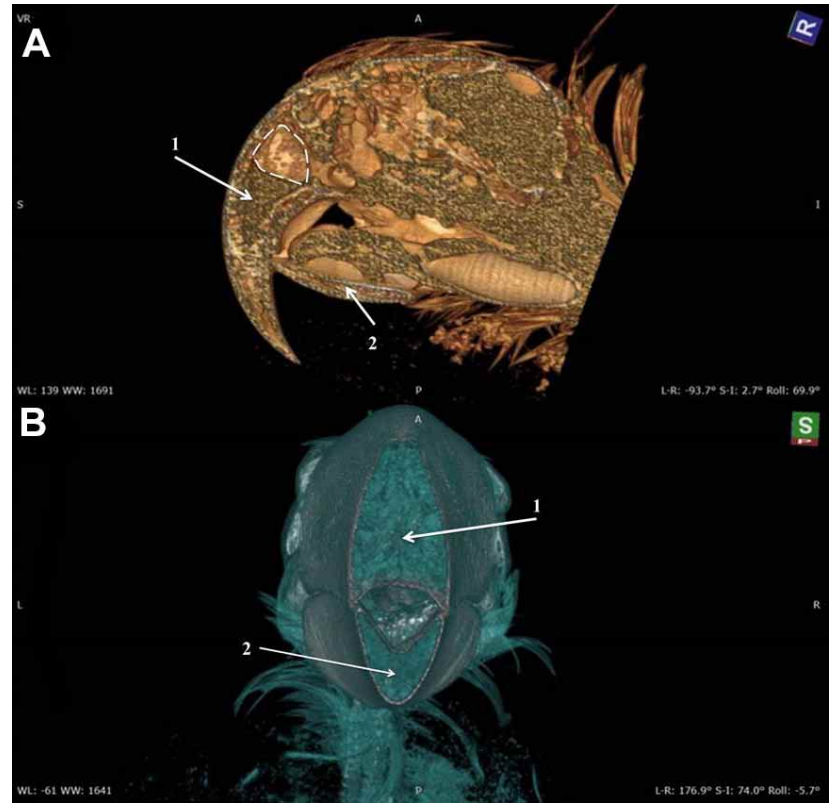

Fig. 5. The maxillary chamber (dashed line), and the trabecular bone network in the maxillary (1) and mandibular (2) parts of the Blueand-yellow Macaw (Ara ararauna) beak (A); and the trabecular bone network in the maxillary (1) and mandibular (2) parts of the Toco Toucan (Ramphastos toco) beak (B) are demonstrated.

the similarities between beak morphology and dietary peculiarities of each species. This enables these species to break and peel hard seeds, and forage for other foods as well (Jones; Sick; Short \& Horne, 2001; Tubelis). Radiological anatomy confirms the importance of the computerized tomography as a valuable resource in virtual dissection. This study highlights the relevance of diagnostic imaging applied to the anatomy of wild animals. Thus, CT was proven to be a useful tool for the visualization of internal structures of the skull of birds, through a detailed virtopsy of regions that are difficult to access by the usual necropsy with a scalpel. Finally, although CT is not a substitute for common dissection, it is an excellent technique to complement traditional macroscopic analysis.

\section{ACKNOWLEDGMENTS}

The authors thank to Prof. Dr. Cláudio Campi de Castro and Mr. Antônio Carlos Matioli for the partnership of University Hospital's imaging sector of the University of São Paulo; to the Coordination for the Improvement of Higher Education Personnel (CAPES) for the financial support to the authors; and to the Profa. Dra. Concepta Margaret McManus Pimentel for the final review of the written language. 
MASSARI, C. H. A. L.; SILVA, A. F.; MAGALHÃES, H. I. R.; SILVA, D. R. S.; SASAHARA, T. H. C. \& MIGLINO, M. A. Anatomía comparada de los picos de guacamayo azul y amarillo (Ara ararauna) y de tucán toco (Ramphastos toco) mediante análisis macroscópico y tomografía computarizada. Int. J. Morphol., 38(6):1591-1596, 2020.

RESUMEN: Debido a la escasa información de la anatomía y de los parámetros fisiológicos que hacen posible los análisis comparativos en la medicina aviar, clínicamente resulta muy difícil el tratamiento de estos animales. Considerando que la tomografía computarizada es una buena alternativa, estudiamos la anatomía comparativa del pico en Ara ararauna y Toco Toucan utilizando imágenes y un análisis de macroscopía. Estos métodos proporcionaron información adicional referente a su conformación y topografía para el trabajo clínico. Después de analizar la tomografía se disecaron las muestras de especímenes adultos y se retiraron los picos para un análisis macroscópico. Los hallazgos macroscópicos y tomográficos para ambas especies corroboraron la relación morfológica entre los picos y las peculiaridades dietéticas de cada uno. Se demostró además, que la tomografía computarizada es una herramienta útil para visualizar las estructuras internas del cráneo de las aves, a través de una virtopsia detallada en áreas de difícil acceso durante una necropsia habitual.

PALABRAS CLAVE: Anatomía de aves; Morfología; Cráneo; Examen de tomografía.

\section{REFERENCES}

Aizawa, J.; Tivane, C.; Rodrigues, M. N.; Wagner, P. G.; Campos, D. B.; Guerra, R. R. \& Miglino, M. A. Gross anatomical features of the gastrointestinal tract (GIT) of blue and yellow Macaws (Ara ararauna) - Oral cavity and pharynx. Anat. Histol. Embryol., 42(6):420-4, 2013.

Altman, R. B. Soft Tissue Surgical Procedures. In: Altman, R. B.; Clubb, S. L.; Dorrestein, G. M. \& Quesenberry, K. (Eds.). Avian Medicine and Surgery. Philadelphia, W. B. Saunders, 1997.

Baumel, J. J.; King, A. S.; Breazile, J. E.; Evans, H. E. \& Berge, J. C. V. Handbook of Avian Anatomy: Nomina Anatomica Avium. Massachusetts, Publications of the Nuttall Ornithological Club, 1993.

Bianchi, C. A. C. Biologia Reprodutiva da Arara-Canindé (Ara ararauna, Psittacidae) no Parque Nacional das Emas, Goiás. Dissertation. Brasilia, Departament of Ecology, University of Brasilia, 1998.

BirdLife International. Birds are Found Almost Everywhere in the World, from the Poles to the Equator. Data Zone, BirdLife International, 2013. Available from: http://datazone.birdlife.org/sowb/casestudy/birds-arefound-almost-everywhere-in-the-world-from-the-poles-to-the-equator

Cubas, Z. S.; Silva, J. C. R. \& Catão-Dias, J. L. Tratado de Animais Selvagens: Medicina Veterinária. 2nd ed. São Paulo, Roca, 2014.

Dislich, M. Piciformes (Tucanos, Araçaris e Pica-paus). In: Cubas, Z. S.; Silva, J. C. R. \& Catão-Dias, J. L. (Eds.). Tratado de Animais Selvagens: Medicina Veterinária. São Paulo, Roca, 2014.

Fecchio, R. S.; Seki, Y.; Bodde, S. G.; Gomes, M. S.; Kolososki, J.; Rossi Jr.,
J. L.; Gioso, M. A. \& Meyers, M. A. Mechanical behavior of prosthesis in Toucan beak (Ramphastos toco). Mater. Sci. Eng. C, 30(3):460-4, 2010.

Hillyer, E. V. Clinical Manifestations of Respiratory Disorders. In: Altman, R. B.; Clubb, S. L.; Dorrestein, G. M. \& Quesenberry, K. (Eds.). Avian Medicine and Surgery. Philadelphia, W. B. Saunders, 1997.

International Committee on Veterinary Gross Anatomical Nomenclature. Nomina Anatomica Veterinaria. Hannover, Editorial Committee, 2017.

Jones, J. S. Evolution: The point of a toucan's bill. Nature, 315:182-3, 1985.

Krautwald-Junghanns, M. E. Birds. In: Krautwald-Junghanns, M. E.; Pees, M. \& Reese, S. (Eds.). Diagnostic Imaging of Exotic Pets: Birds, Small Mammals, Reptiles. Hannover, Schlutersche Verlagsgesellschaft GmbH, 2010.

Ministério do Meio Ambiente. $5^{\circ}$ Relatório Nacional para a Convenção sobre Diversidade Biológica. Brasilia, Ministério do Meio Ambiente de Brazil, 2016.

Orosz, S. Anatomy of the Respiratory System. In: Altman, R. B.; Club, S. L.; Dorrestein, G. M. \& Quesenberry, K. (Eds.). Avian Medicine and Surgery. Philadelphia, W. B. Saunders, 1997.

Pye, G. W.; Bennett, R. A.; Newell, S. M.; Kindred, J. \& Johns, R. Magnetic resonance imaging in Psittacine birds with chronic sinusitis. J. Avian Med. Surg., 14(4):243-56, 2000.

Ruffini, A. Fisiogenia; La Biodinamica Dello Sviluppo Ed I Fondamentali Problemi Morfologici Dell'embriologia Generale. Milano, Vallardi, 1925.

Scherer-Neto, P.; Straube, F. C.; Carrano, E. \& Urben-Filho, A. Lista das Aves do Paraná. Curitiba, Hori Cadernos Técnicos, 2011.

Seki, Y.; Bodde, S. G. \& Meyers, M. A. Toucan and hornbill beaks: A comparative study. Acta Biomater, 6(2):331-43, 2010.

Seki, Y.; Kad, B.; Benson, D. \& Meyers, M. A. The toucan beak: Structure and mechanical response. Mater. Sci. Eng. C, 26(8):1412-20, 2006.

Short, L. \& Horne, J. Toucans, Barbets and Honeyguides. Oxford, Oxford University Press, 2001.

Short, L. L. \& Horne, F. M. Family Ramphastidae (Toucans). In: Del Hoyo, J.; Elliot, A. \& Sargatal, J. (Eds.). Handbook of the Birds of the World. Barcelona, Lynx Edicions, 2002.

Sick, H. Ornitologia Brasileira. Rio de Janeiro, Editor Nova Fronteira, 1997. Tattersall, G. J.; Andrade, D. V. \& Abe, A. S. Heat exchange from the toucan bill reveals a controllable vascular thermal radiator. Science, 325(5939):468-70, 2009.

Tubelis, D. P. Feeding ecology of Ara ararauna (Aves, Psittacidae) at firebreaks in western Cerrado, Brazil. Biotemas, 22(2):105-15, 2009.

Veladiano, I. A.; Banzato, T.; Bellini, L.; Montani, A.; Catania, S. \& Zotti, A. Computed tomographic anatomy of the heads of blue-and-gold macaws (Ara ararauna), African grey parrots (Psittacus erithacus), and monk parakeets (Myiopsitta monachus). Am. J. Vet. Res., 77(12):1346-56, 2016.

Corresponding author:

Prof. Dr. Maria Angélica Miglino

University of São Paulo - USP

Department of Surgery

School of Veterinary Medicine and Animal Sciences

Av. Prof. Dr. Orlando Marques de Paiva, 87

05508-270 - São Paulo - SP

Brazil

Email: miglino@usp.br

Received:04-05-2020

Accepted:11-07-2020 